\title{
Spatial Variability of Heavy Metals in Soils and Sediments of "La Zacatecana" Lagoon, Mexico
}

\author{
Sergio A. Covarrubias $\left(\mathbb{D},{ }^{1}\right.$ Juan Armando Flores de la Torre, ${ }^{2,3}$ María Maldonado Vega, \\ Francisco Javier Avelar González, ${ }^{2}$ and Juan José Peña Cabriales $\mathbb{D}^{1}$ \\ ${ }^{1}$ Laboratorio de Microbiología Ambiental, Departamento de Bioquímica y Biotecnología, Centro de Investigaciones y Estudios \\ Avanzados del Instituto Politécnico Nacional, Unidad Irapuato, Irapuato, GTO, Mexico \\ ${ }^{2}$ Universidad Autónoma de Aguascalientes, Avenida Universidad No. 940, Aguascalientes 20231, AGS, Mexico \\ ${ }^{3}$ Universidad Autónoma de Zacatecas, Unidad Académica de Ciencias Químicas, Campus Siglo XXI, Zacatecas, ZAC, Mexico \\ ${ }^{4}$ Dirección de Planeación, Enseñanza e Investigación del Hospital Regional de Alta Especialidad del Bajío, Leon, GTO, Mexico \\ Correspondence should be addressed to Juan José Peña Cabriales; jpena@ira.cinvestav.mx
}

Received 29 August 2017; Accepted 19 November 2017; Published 21 January 2018

Academic Editor: Rafael Clemente

Copyright ( 2018 Sergio A. Covarrubias et al. This is an open access article distributed under the Creative Commons Attribution License, which permits unrestricted use, distribution, and reproduction in any medium, provided the original work is properly cited.

\begin{abstract}
Anthropogenic activities have greatly increased heavy metal pollution worldwide. Due to inadequate waste management, mining is one of the chief causes. One particularly affected area in Mexico is the "La Zacatecana" Lagoon, in the municipality of Guadalupe, Zacatecas. From colonial times until the mid-nineteenth century, about 20 million tons of mine tailings were deposited at this site. Here, we catalogue the heavy metal content and their distribution in soils and sediments of La Zacatecana. The mobility of lead in soils was also assayed by sequential extraction. Concentrations of the different metals analysed were as follows: $\mathrm{Pb}>\mathrm{Cr}>\mathrm{As}>\mathrm{Ni}>\mathrm{Hg}>\mathrm{Cd}$. Site VIII accumulated the highest amount of $\mathrm{Pb}\left(3070 \mathrm{mg} \cdot \mathrm{kg}^{-1}\right)$ sevenfold more than the limit established by the Mexican standards for agricultural soils (i.e., $400 \mathrm{mg} \cdot \mathrm{kg}^{-1}$ ). On the other hand, the contents of Cd, Cr, and $\mathrm{Ni}$ were within the levels accepted by the above normativity, set at 37, 280, and $1600 \mathrm{mg} \cdot \mathrm{kg}^{-1}$, respectively. Concentrations of $\mathrm{Hg}$ and $\mathrm{Pb}$ were highest in the north-northwest zone of the lagoon and decreased towards the southeast. Except for Site VIII where $30 \%$ of the $\mathrm{Pb}$ was in an interchangeable form or bound to carbonates, most $\mathrm{Pb}$ in La Zacatecana soils was present in an unavailable form, associated with Fe-Mn oxides.
\end{abstract}

\section{Introduction}

Heavy metal pollution is largely attributable to human activities, especially mining. Extraction and purification of minerals generates vast amounts of solid wastes (also called mine tailings) that degrade soils and render them unsuitable for agriculture. Mining contributes greatly to soil degradation by generating waste that generally occupies large areas [1]. Much mining waste still contains large quantities of heavy metals that move through the environment in changed redox states. Once in soils, metals can enter the trophic chain via accumulation in plants [2], causing both environmental and animal health problems.
Mexico is one of the countries most affected by heavy metal pollution of soils, especially in the state of Zacatecas, the most important producer of silver in the country. The mine tailings from the old mining district of Zacatecas (located in the municipality of Guadalupe, Zacatecas) were deposited in the La Zacatecana Lagoon from the beginning of the Colonial period until the early XIX century. From 1920 to 2010, processing of tailings for the recovery of mercury also occurred $[3,4]$. Since then, this zone has been used for agriculture, especially to cultivate beans and maize, but reports of accumulation of arsenic and lead in tissues of these plants have been published [5].

Studies of mercury levels and other toxic metals have been conducted in the La Zacatecana Lagoon [6], but 


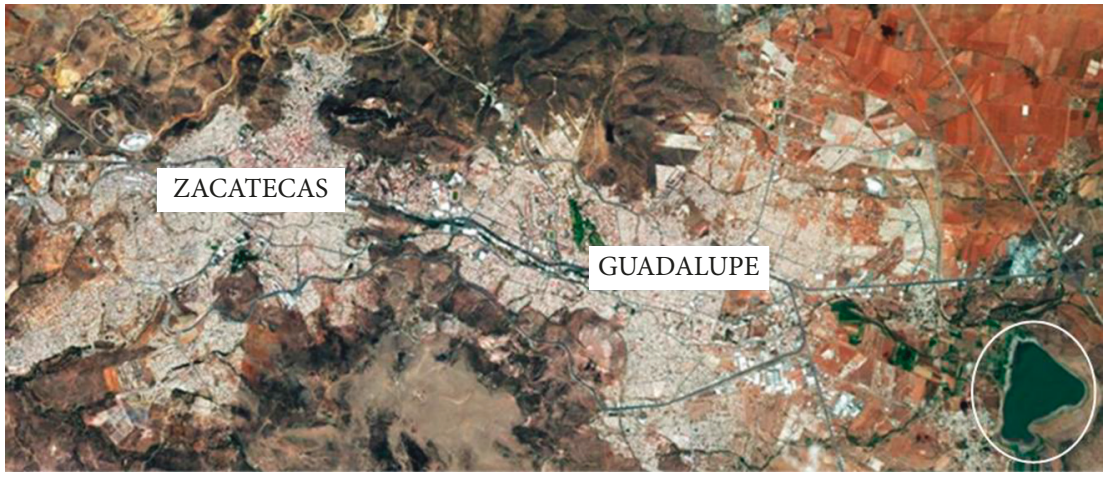

(a)

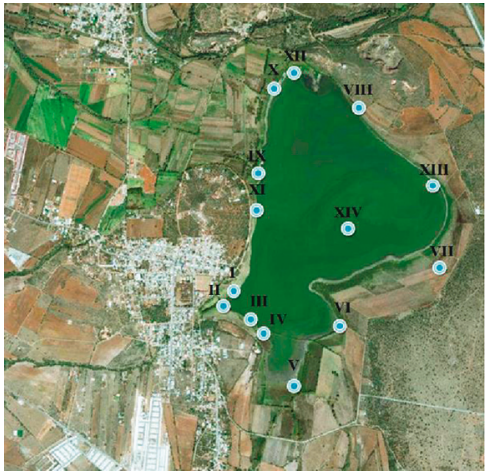

(b)

Figure 1: The Zacatecas metropolitan area. (a) Location of the La Zacatecana Lagoon in reference to the cities of Zacatecas and Guadalupe. (b) Sampling sites in the La Zacatecana Lagoon.

detailed assessments of the spatial distribution and the availability of metals, especially lead, have not been undertaken. As the impact of toxic metals percolates throughout the food chain, we set out to fill the gaps in knowledge by (1) determining the total contents and distribution patterns of metals in soils and sediments, (2) evaluating the mobility of lead in soils by sequential extraction techniques, and (3) assessing the ecological risk of heavy metal contamination in the La Zacatecana Lagoon.

\section{Materials and Methods}

2.1. Site Description. The "La Zacatecana" Lagoon is located in the municipality of Guadalupe $\left(22^{\circ} 44^{\prime} 50^{\prime \prime} \mathrm{N}, 102^{\circ} 28^{\prime} 10^{\prime \prime} \mathrm{W}\right)$ in the southeastern corner of the state of Zacatecas, Mexico (Figure 1) and has a flood extension area of 200 ha. The nearby town of La Zacatecana has approximately 3200 inhabitants. With an annual average temperature of $16^{\circ} \mathrm{C}$, an average rainfall of $510 \mathrm{~mm}$, and at an altitude of 2400 meters above the sea level, the climate is dry.

2.2. Soil Sampling and Characterization. Soil and sediment samples were gathered during the rainy season in May 2015. Fourteen samples from different parts of the lagoon were collected. Before analysis, the samples were air-dried at room temperature, milled, and sieved through a $2 \mathrm{~mm}$ nylon mesh. The total concentration of metals was determined according to the EPA Method 7000B [7]. Approximately $0.5 \mathrm{~g}$ of soils and sediments were digested overnight in $10 \mathrm{~mL}$ of $\mathrm{HNO}_{3}$ contained in Erlenmeyer flasks. The samples were then heated at $120^{\circ} \mathrm{C}$ for $3 \mathrm{~h}$. After cooling, the samples were filtered through \#50 Whatman cellulose filters. Total metal contents of the samples were determined using atomic absorption spectrophotometry and a flame-ionisation detector (PinAAcle 900H; PerkinElmer, Waltham, MA, USA). NIST SRM-2586 (Trace Elements in Soil Containing Lead from Paint) was used as the standard reference material (National Institute of Standards and Technology, Gaithersburg, MD, USA).

$\mathrm{pH}$ was measured in soil suspensions with deionised water. Electrical conductivity (EC) was determined in the soil-water extracts using a conductivity meter (HI 98130, Combo Hanna Instruments, Woonsocket, RI, USA). Organic matter $(\mathrm{OM})$ was determined by the Walkley-Black metric titration method [8]. Redox potential was measured potentiometrically.

2.3. Spatial Distribution of Heavy Metals. Spatial distribution maps of metals were generated from Kriging interpolation data from sampling sites using Surfer 9 (Golden Software, LLC).

2.4. Geoaccumulation Index and Potential Ecological Risk Assessment. Müller [9] proposed the Geoaccumulation Index $\left(I_{\text {geo }}\right)$ to assess metal pollution in soils and sediments. $I_{\text {geo }}$ was calculated as follows:

$$
I_{\text {geo }}=\log _{2}\left(\frac{C_{n}}{1.5 B_{n}}\right)
$$

where $C_{n}$ is the measured concentration of metals in soil and $B_{n}$ is the background value of the metals, in this case, the mean concentration of metals in soil from a control site (without mining activity) in Zacatecas State. The values obtained were $13,2.7$, and $8 \mathrm{mg} \cdot \mathrm{kg}^{-1}$ for $\mathrm{Pb}, \mathrm{As}$, and $\mathrm{Hg}$, respectively. High levels of $\mathrm{Cr}$ and $\mathrm{Ni}\left(74\right.$ and $40 \mathrm{mg} \cdot \mathrm{kg}^{-1}$, respectively) were found, but the Cd levels $\left(0.9 \mathrm{mg} \cdot \mathrm{kg}^{-1}\right)$ were low. Due to lithogenic effects, 1.5 was the background matrix correction factor. The $I_{\text {geo }}$ values were compared with the seven classes proposed by Müller [9] (Table 1).

Hakanson [10] introduced the potential ecological risk assessment $\left(E_{\mathrm{RI}}\right)$ as a diagnostic tool for metal-polluted environments. $E_{\mathrm{RI}}$ is calculated as follows:

$$
\begin{aligned}
& E_{r}^{i}=T_{r}^{i} \times \frac{C^{i}}{C_{0}^{i}}, \\
& E_{\mathrm{RI}}=\sum_{i=1}^{7} E_{r}^{i} .
\end{aligned}
$$

where $E_{r}^{i}$ is the monomial potential ecological risk factor, $C^{i}$ is the concentration of the specific metal (and $C_{0}^{i}$ is the 
TABLE 1: Classification of pollution intensity as proposed by Müller [9].

\begin{tabular}{lcc}
\hline & Class & Pollution intensity \\
\hline$<0$ & 0 & Unpolluted \\
$0-1$ & 1 & Unpolluted to moderately polluted \\
$1-2$ & 2 & Moderately polluted \\
$2-3$ & 3 & Moderately to heavily polluted \\
$3-4$ & 4 & Heavily polluted \\
$5-6$ & 5 & Extremely polluted \\
$>6$ & 6 & \\
\hline
\end{tabular}

background reference value), and $T_{r}^{i}$ is the metal toxicity factor $(\mathrm{Pb}$ and $\mathrm{Ni}=5, \mathrm{As}=10, \mathrm{Hg}=40, \mathrm{Cd}=30$, and $\mathrm{Cr}=2)$. $E_{\mathrm{RI}}$ 's are then categorised as follows: $E_{\mathrm{RI}}<150$, low ecological risk; $150<E_{\mathrm{RI}}<300$, moderate ecological risk; $300<E_{\mathrm{RI}}<600$, considerable ecological risk; and $E_{\mathrm{RI}}>600$, very high ecological risk.

2.5. Soil Lead Fractionation. Lead fractionation in soils was determined according to the Tessier five-step protocol [11]. Exchangeable $\mathrm{Pb}$ (F1), $\mathrm{Pb}$ bound to carbonate (F2), $\mathrm{Pb}$ bound to Fe-Mn oxides (F3), Pb bound to organic matter (F4), and residual PB (F5) were determined on $1 \mathrm{~g}$ of soil. The lead content was measured by flame-ionisation atomic absorption spectrometry.

2.6. Data Analysis. The XLSTAT software version 2017.1 was used to calculate the statistics. One-way ANOVA tests were used to determine differences in metal contents between sample sites, followed by Tukey's post hoc test. Correlation analyses were applied to seek a possible common source of metals.

\section{Results and Discussion}

3.1. Total Metal Concentrations and Soil Properties. Lead was the most abundant heavy metal found while chromium, arsenic, etc. were present in decreasing amounts $(\mathrm{Pb}>\mathrm{Cr}>\mathrm{As}>\mathrm{Ni}>\mathrm{Hg}>\mathrm{Cd}) .3070 \mathrm{mg} \cdot \mathrm{kg}^{-1} \mathrm{~Pb}$ was found at Site VIII, which is seven times higher than Mexican reference for agricultural soils $\left(400 \mathrm{mg} \cdot \mathrm{kg}^{-1}\right)$. Total metal contents obtained here (Table 2) were compared with the Mexican guideline sNOM-147 [12] and with the Canadian Environmental Quality Guidelines (CEQGs) for agricultural soil, which are as follows: $\mathrm{As}=12, \mathrm{Cd}=1.4, \mathrm{Cr}=64, \mathrm{Hg}=6.6$, $\mathrm{Ni}=45$, and $\mathrm{Pb}=70\left(\mathrm{mg} \cdot \mathrm{kg}^{-1}\right)$ [13]. Hg and $\mathrm{Pb}$ concentrations were higher than Mexican reference values at some sampling sites, while $\mathrm{Cd}, \mathrm{Cr}$, and $\mathrm{Ni}$ concentrations did not surpass the limits set by the same norm $(37,280$, and $1600 \mathrm{mg} \cdot \mathrm{kg}^{-1}$, resp.) at any site. On the contrary, all sampling sites had $\mathrm{Hg}$ and As concentrations that surpassed those established by the CEQGs, while Pb levels were within the limit (i.e., $70 \mathrm{mg} \cdot \mathrm{kg}^{-1}$ ) only in Sites V, VI, and VII. A similar situation was found for $\mathrm{Cd}, \mathrm{Cr}$, and $\mathrm{Ni}$ concentrations, which exceeded the CEQGs at some sampling points (Table 2).
The total concentration of As in La Zacatecana soils was considerably lower than that found at other places. The $991 \mathrm{mg} \cdot \mathrm{kg}^{-1}$ of arsenic found by Iskander et al. [6] was almost 10 times higher than the maximum content of arsenic founded here $\left(101 \mathrm{mg} \cdot \mathrm{kg}^{-1}\right)$. The maximum concentration of $\mathrm{Hg}$ in the soil $\left(47 \mathrm{mg} \cdot \mathrm{kg}^{-1}\right)$ was similar to the concentrations founded by Santos-Santos et al. [14] and Gavilán-García et al. [3] with 36 and $48 \mathrm{mg} \cdot \mathrm{kg}^{-1}$, respectively.

More recently, Gonzalez-Davila et al. [5] reported the disposal of new tailings in the La Zacatecana Lagoon, finding concentrations of $\mathrm{Pb}, \mathrm{As}$, and $\mathrm{Hg}$ of 5660, 290, and $506 \mathrm{mg} \cdot \mathrm{kg}^{-1}$, respectively, near Site VIII. Obviously, recently deposited tailings contain higher concentrations of heavy metals that leach-out over time and migrate through the soil profile to the deeper layers [15]. Since sampling in this study was restricted to a depth of $30 \mathrm{~cm}$, we were not able to analyse this phenomenon.

Correlations between $\mathrm{Pb}, \mathrm{As}$, and $\mathrm{Hg}$ (Table 3) were positive and significant at $p<0.05$, indicating a common source for these elements in the La Zacatecana Lagoon soils, which could be anthropogenic due to its higher values comparing to the control site. On the other hand, $\mathrm{Cd}, \mathrm{Cr}$, and $\mathrm{Ni}$ also showed a positive correlation, which suggested a different origin for these metals. In this regard, Çevik et al. [16] and Shafie et al. [17] suggested that relationships between metals may vary significantly depending on their geochemical origin, including parent material of the soil and soil type.

Alkaline $\mathrm{pH}$ conditions prevailed in soils and sediment samples (Table 4). The highest $\mathrm{pH}$ value (9.6) was found at Site III, whereas the minimum value of 7.7 was observed at Site VII. High $\mathrm{pH}$ reduces $\mathrm{Pb}$ and $\mathrm{Cd}$ availability in soils through complex formation with Fe-Mn oxyhydroxides [18]. Salinity, measured as metal conductivity $\left(\mathrm{dS} \cdot \mathrm{m}^{-1}\right)$ in La Zacatecana Lagoon soils, was normal based on USDA (2002) classifications.

To a large extent, organic matter (OM) content determines the mobility and bioavailability of heavy metals in soils. Metals can form stable complexes with humic substances present in organic matter [19]. Almost $60 \%$ of the sampling sites had high organic matter contents of more than $2 \%$. Site I was highest amount (OM of $4.6 \%$ ), while Site XIV had only $1.2 \%$ OM.

Of the parameters measured, redox potential varied the most, ranging from -121 to $308 \mathrm{mV}$. Based on the findings of others [20,21], most of the La Zacatecana Lagoon soils and sediments could be classified as reduced or moderately reduced ( $E h$ between -100 and $+400 \mathrm{mV}$ ). Only Site I corresponded to a highly reduced soil $(E h-121 \mathrm{Eh})$. This is important because under reducing conditions, the availability of metals is reduced due to formation of insoluble compounds with sulphide and the increase of the adsorption of metals on $\mathrm{Mn}$ and $\mathrm{Fe}$ oxides [22]. Under oxidizing conditions, the solubility of the metals in water increases, as they are more likely to be found in the free ionic form [23].

3.2. Spatial Distribution of Metals. Similar patterns of spatial distribution were observed for $\mathrm{Pb}, \mathrm{As}$, and $\mathrm{Hg}$ (Figure 2). 
TABLE 2: Mean values and standard errors of heavy metal concentrations in soils and sediments from the La Zacatecana Lagoon. Sites denoted by different letters in the same column differ significantly at $p<0.05$ in one-way ANOVA, according to Tukey's post hoc analysis. Metal concentrations are expressed as $\mathrm{mg} \cdot \mathrm{kg}^{-1}$.

\begin{tabular}{|c|c|c|c|c|c|c|}
\hline Sampling site & $\mathrm{Pb}$ & As & $\mathrm{Hg}$ & $\mathrm{Cd}$ & $\mathrm{Cr}$ & $\mathrm{Ni}$ \\
\hline I & $94 \pm 4 \mathrm{e}$ & $30 \pm 0.9 \mathrm{~cd}$ & $38 \pm 2.9 \mathrm{abc}$ & $16 \pm 0.02 \mathrm{~b}$ & $74 \pm 2.4 \mathrm{a}$ & $76 \pm 1.6 \mathrm{a}$ \\
\hline II & $162 \pm 42 \mathrm{de}$ & $27 \pm 1 \mathrm{de}$ & $41 \pm 11 \mathrm{bc}$ & ND & $19 \pm 0.9$ efg & $19.9 \pm 1.0 \mathrm{~d}$ \\
\hline III & $121 \pm 2.7 \mathrm{de}$ & $21 . \pm 1.4 \mathrm{efg}$ & $15 \pm 4.8 \mathrm{bcd}$ & ND & $32 \pm 0.7 \mathrm{~d}$ & $23 \pm 1.2 \mathrm{~d}$ \\
\hline IV & $72 \pm 1.8 \mathrm{e}$ & $19 \pm 0.8 \mathrm{fg}$ & $18 \pm 4.3 \mathrm{bcd}$ & $21 \pm 0.1 \mathrm{a}$ & $64 \pm 0.4 \mathrm{~b}$ & $60 \pm 0.7 \mathrm{~b}$ \\
\hline V & $60 \pm 9.4 \mathrm{e}$ & $17 \pm 1.3 \mathrm{~g}$ & $12 \pm 6.3 \mathrm{~cd}$ & ND & $18 \pm 0.9$ efg & $15 \pm 0.5 \mathrm{e}$ \\
\hline VI & $48 \pm 4.8 \mathrm{e}$ & $16 \pm 2.1 \mathrm{gh}$ & $7.9 \pm 4 \mathrm{~d}$ & ND & $22 \pm 0.6$ efg & $9 \pm 0.1 \mathrm{fg}$ \\
\hline VII & $29 \pm 1.2 \mathrm{e}$ & $9.3 \pm 1.1 \mathrm{~h}$ & $7.7 \pm 1.3 \mathrm{~d}$ & ND & $19 \pm 0.6 \mathrm{efg}$ & $9 \pm 0.2 \mathrm{fg}$ \\
\hline VIII & $3070 \pm 20 \mathrm{a}$ & $28 \pm 1.4 \mathrm{cde}$ & $10 \pm 0.3 \mathrm{~cd}$ & ND & $17 \pm 1.4$ efg & $6 \pm 0.2 \mathrm{~g}$ \\
\hline IX & $545 \pm 44 c$ & $35 \pm 1.2 c$ & $47 \pm 11 \mathrm{a}$ & ND & $17 \pm 1.0 \mathrm{fg}$ & $10 \pm 0.3$ ef \\
\hline $\mathrm{X}$ & $742 \pm 62 b$ & $80 \pm 1.4 b$ & $47 \pm 8.2 \mathrm{a}$ & ND & $15 \pm 1.4 \mathrm{~g}$ & $14 \pm 0.5 \mathrm{e}$ \\
\hline XI & $88 \pm 3$ e & $18 \pm 0.4 \mathrm{~g}$ & $9 \pm 0.1 \mathrm{~d}$ & ND & $25 \pm 1$ def & $24 \pm 0.5 \mathrm{~d}$ \\
\hline XII & $760 \pm 71 \mathrm{~b}$ & $101 \pm 2.8 \mathrm{a}$ & $24 \pm 0.2 \mathrm{abcd}$ & $8 \pm 0.1 c$ & $67 \pm 3.6 \mathrm{ab}$ & $74 \pm 1.4 \mathrm{a}$ \\
\hline XIII & $87 \pm 6.3 \mathrm{e}$ & $17 \pm 0.8 \mathrm{~g}$ & $8 \pm 0.1 \mathrm{~d}$ & ND & $25 \pm 0.7 \mathrm{de}$ & $22 \pm 0.2 \mathrm{~d}$ \\
\hline XIV & $280 \pm 31 \mathrm{~d}$ & $26 \pm 1.3 \mathrm{de}$ & $12 \pm 0.3 \mathrm{~cd}$ & ND & $44 \pm 0.9 \mathrm{c}$ & $42 \pm 0.7 c$ \\
\hline
\end{tabular}

$\mathrm{ND}=$ nondetected.

TABLE 3: Correlation matrices of metal concentrations.

\begin{tabular}{lcccccc}
\hline Metals & $\mathrm{Pb}$ & $\mathrm{As}$ & $\mathrm{Hg}$ & $\mathrm{Cd}$ & $\mathrm{Cr}$ & - \\
$\mathrm{Pb}$ & 1.00 & - & - & - & - & - \\
$\mathrm{As}$ & $0.86^{* *}$ & 1.00 & - & - & - \\
$\mathrm{Hg}$ & $0.52^{*}$ & $0.59^{* *}$ & 1.00 & - & - & - \\
$\mathrm{Cd}$ & -0.11 & 0.24 & 0.23 & 0.02 & $0.74^{* *}$ & - \\
$\mathrm{Cr}$ & -0.19 & 0.01 & $0.73^{* *}$ & 1.00 & $0.86^{* *}$ \\
$\mathrm{Ni}$ & 0.12 & 0.32 & & & - \\
\hline
\end{tabular}

${ }^{*} p<0.05 ;{ }^{* *} p<0.01$.

TABLE 4: Mean and standard errors of physicochemical characteristics of soils and sediments from the La Zacatecana Lagoon. Sites denoted by different letters in the same column differ significantly at $p<0.05$ in one-way ANOVA tests (Tukey's post hoc analysis).

\begin{tabular}{lcccc}
\hline Sampling sites & $\mathrm{pH}$ & Electrical conductivity $(\mathrm{dS} / \mathrm{m})$ & Organic matter content $(\%)$ & Redox potential $(\mathrm{mV})$ \\
\hline I & $8.7 \pm 0.1 \mathrm{~cd}$ & $1.7 \pm 0.1 \mathrm{~b}$ & $4.3 \pm 0.2 \mathrm{a}$ & $-121 \pm 19 \mathrm{~h}$ \\
II & $8.5 \pm 0.1 \mathrm{de}$ & $0.7 \pm 0.05 \mathrm{f}$ & $1.5 \pm 0.05 \mathrm{ef}$ & $12 \pm 6 \mathrm{fg}$ \\
III & $9.6 \pm 0.1 \mathrm{a}$ & $1.2 \pm 0.1 \mathrm{~d}$ & $1.7 \pm 0.1 \mathrm{e}$ & $14 \pm 5 \mathrm{fg}$ \\
IV & $9 \pm 0.1 \mathrm{~b}$ & $1.7 \pm 0.1 \mathrm{~b}$ & $1.5 \pm 0.1 \mathrm{ef}$ & $194 \pm 13 \mathrm{bc}$ \\
V & $8.3 \pm 0.00 \mathrm{e}$ & $1 \pm 0.05 \mathrm{e}$ & $2.9 \pm 0.1 \mathrm{c}$ & $26 \pm 7 \mathrm{f}$ \\
VI & $8.5 \pm 0.01 \mathrm{de}$ & $1.3 \pm 0.05 \mathrm{c}$ & $2.6 \pm 0.1 \mathrm{~cd}$ & $23 \pm 4 \mathrm{fg}$ \\
VII & $7.7 \pm 0.1 \mathrm{~g}$ & $0.4 \pm 0.05 \mathrm{~g}$ & $2.3 \pm 0.1 \mathrm{~d}$ & $86 \pm 27 \mathrm{e}$ \\
VIII & $7.8 \pm 0.1 \mathrm{~g}$ & $2 \pm 0.00 \mathrm{a}$ & $1.6 \pm 0.10 \mathrm{ef}$ & $308 \pm 0.3 \mathrm{a}$ \\
IX & $8 \pm 0.05 \mathrm{f}$ & $1 \pm 0.02 \mathrm{e}$ & $3.9 \pm 0.1 \mathrm{ab}$ & $109 \pm 3 \mathrm{de}$ \\
X & $7.8 \pm 0.05 \mathrm{fg}$ & $1.6 \pm 0.05 \mathrm{~b}$ & $3.6 \pm 0.1 \mathrm{~b}$ & $149 \pm 6 \mathrm{~cd}$ \\
XI & $8.9 \pm 0.05 \mathrm{bc}$ & $1.3 \pm 0 \mathrm{~cd}$ & $1.2 \pm 0.05 \mathrm{f}$ & $271 \pm 6 \mathrm{a}$ \\
XII & $8.9 \pm 0.05 \mathrm{bc}$ & $0.8 \pm 0 \mathrm{f}$ & $2.4 \pm 0.05 \mathrm{~d}$ & $202 \pm 6 \mathrm{~b}$ \\
XIII & $8.9 \pm 0.05 \mathrm{bc}$ & $19 \pm 0 \mathrm{a}$ & $3.4 \pm 0.1 \mathrm{~b}$ & $-6.5 \pm 8.8 \mathrm{fg}$ \\
XIV & $8.9 \pm 0.05 \mathrm{bc}$ & $0.9 \pm 0.01 \mathrm{e}$ & $1.2 \pm 0.05 \mathrm{f}$ & $-26 \pm 10 \mathrm{~g}$ \\
\hline
\end{tabular}

The hot-spot areas of these metals were located in the northern area of the lagoon. This area coincides with the recent disposal of tailings reported by Gonzalez-Davila et al. [5]. As expected, the distribution of heavy metals declined in 


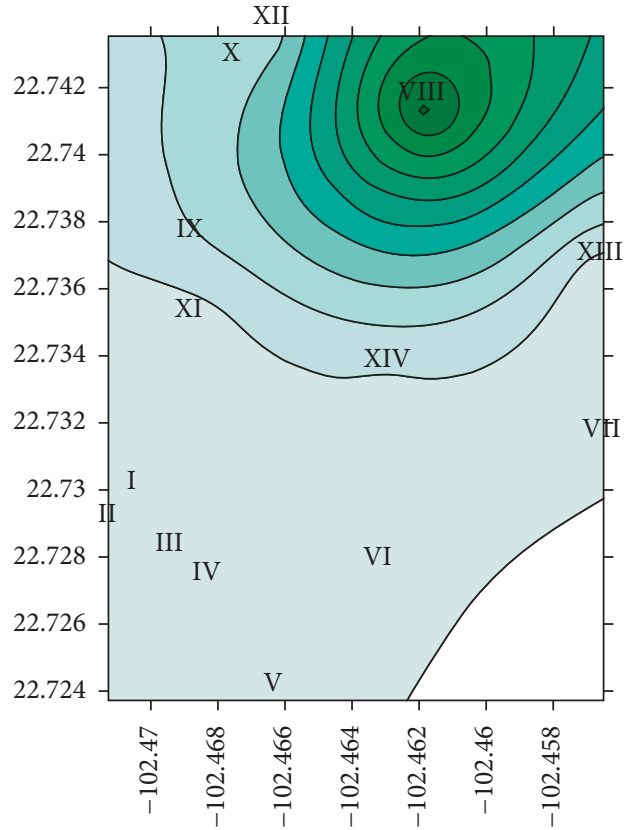

(a)

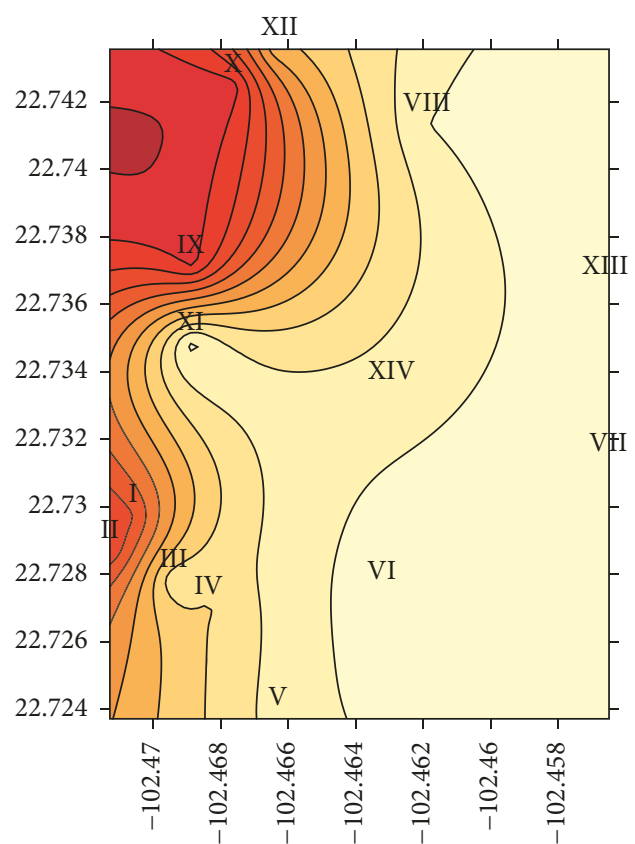

(c)

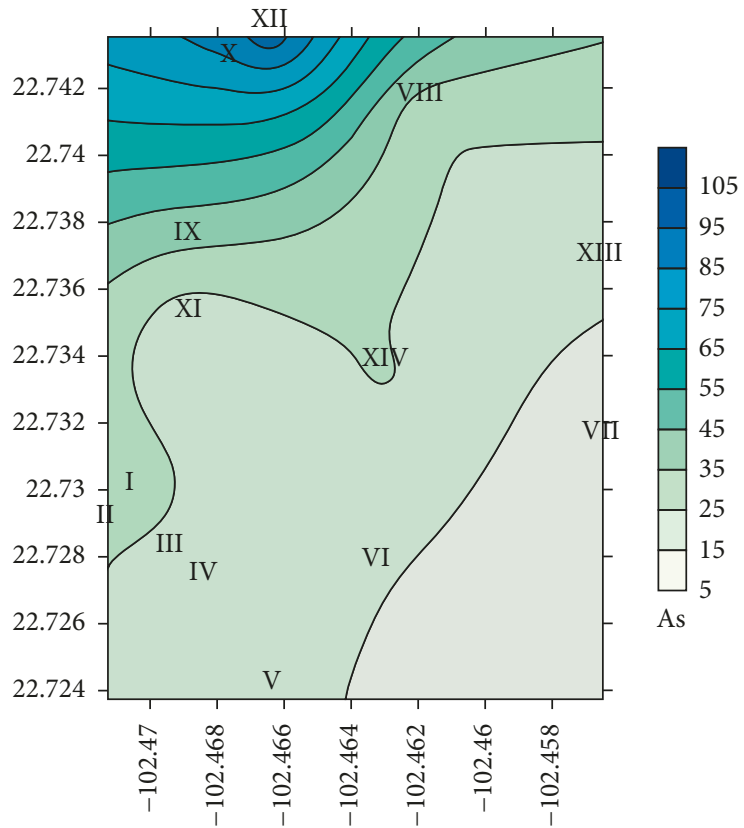

(b)

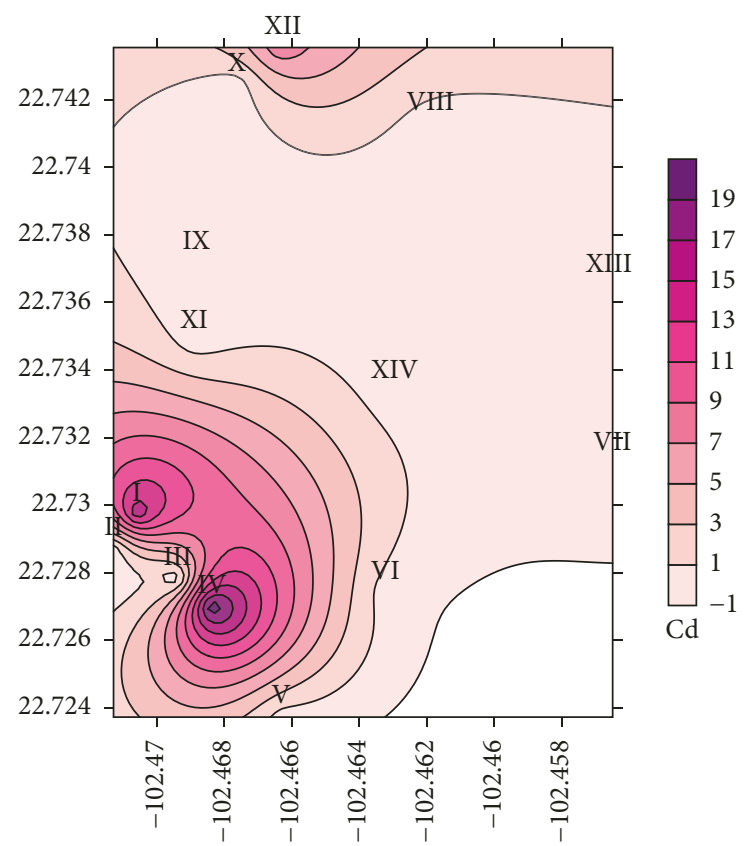

(d)

Figure 2: Continued. 


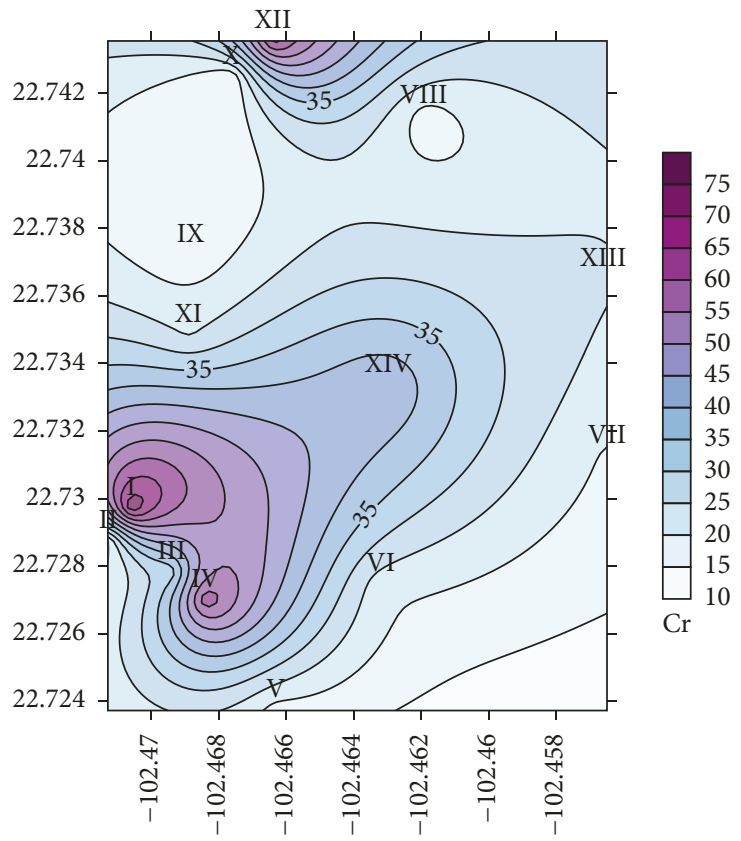

(e)

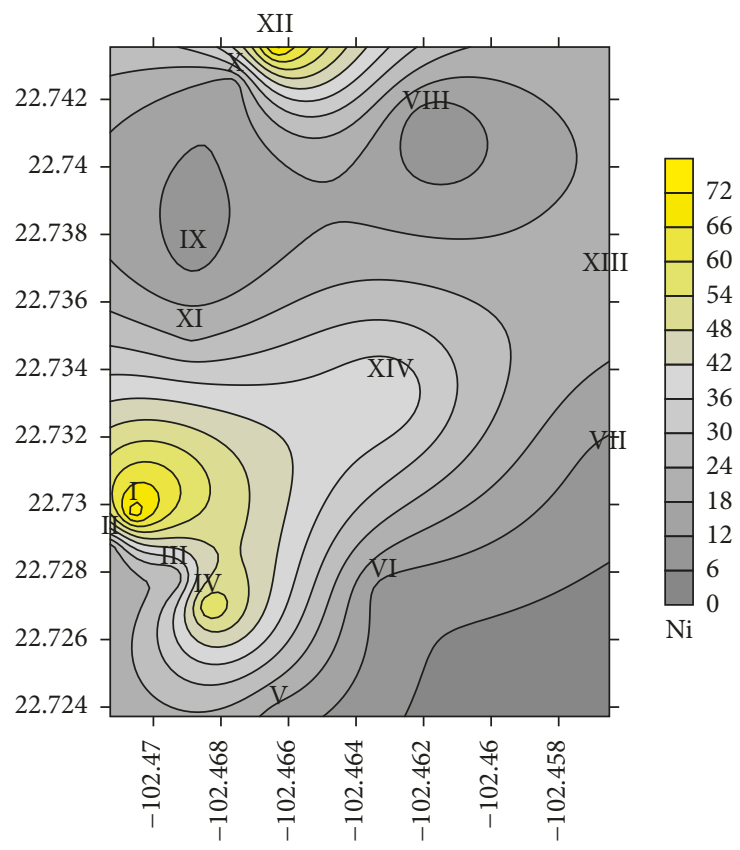

(f)

FIGURE 2: Spatial distribution of heavy metal concentrations in the area of the La Zacatecana Lagoon. (a) Lead, (b) arsenic, (c) mercury, (d) cadmium, (e) chromium, and ( $\mathrm{f}$ ) nickel. Values are expressed as $\mathrm{mg} \cdot \mathrm{kg}^{-1}$.

the southwesterly direction. Conversely, the maximum concentrations of Cd, Cr, and Ni were observed at Sites I and IV in the southeast area of the lagoon. As we previously mentioned, $\mathrm{Cd}, \mathrm{Cr}$, and Ni were positively correlated, which corresponds with the spatial distribution shown for these metals.

3.3. Fractionation of Lead in Soils. The sequential extraction procedure that was used to determine lead availability in the La Zacatecana samples showed a predominance of $\mathrm{Pb}$ bound to Fe- and Mn-oxides (F3) over carbonate bound fractions (F2), followed by organic matter associated fractions (F4) (57\% 19.4\% and 19\% resp.) (Figure 3). Significant differences $(p<0.05)$ were found between F4 and F2. Pb associated with the residual fraction (F5) represented $4.5 \%$ of the total, whereas the exchangeable fraction (F1) was very low $(0.1 \%)$.

At $29 \%$, Site VIII had the highest amount of easily mobilisable $\mathrm{Pb}(\mathrm{F} 1, \mathrm{~F} 2)$, representing $896 \mathrm{mg} \cdot \mathrm{kg}^{-1}$ of $\mathrm{Pb}$ that could be released from the soil matrix. Steinnes [24] suggested that $\mathrm{Pb}$ availability depends to a large extent on the percent soil organic matter since at low $\mathrm{pH}(<5) \mathrm{Pb}$ is strongly bound to humic acids [25]. This hypothesis is in agreement with the date reported for Site VIII, which had the lowest percentage of organic matter $(1.6 \%)$ and a neutral to slightly alkaline $\mathrm{pH}$. At these $\mathrm{pHs}, \mathrm{Pb}$ solubility can be increased due to the formation of Pb-hydroxyl complexes [26].

3.4. Geoaccumulation Index and Environmental Risk Assessment. Based on the Müller scale, the calculated $I_{\text {geo }}$

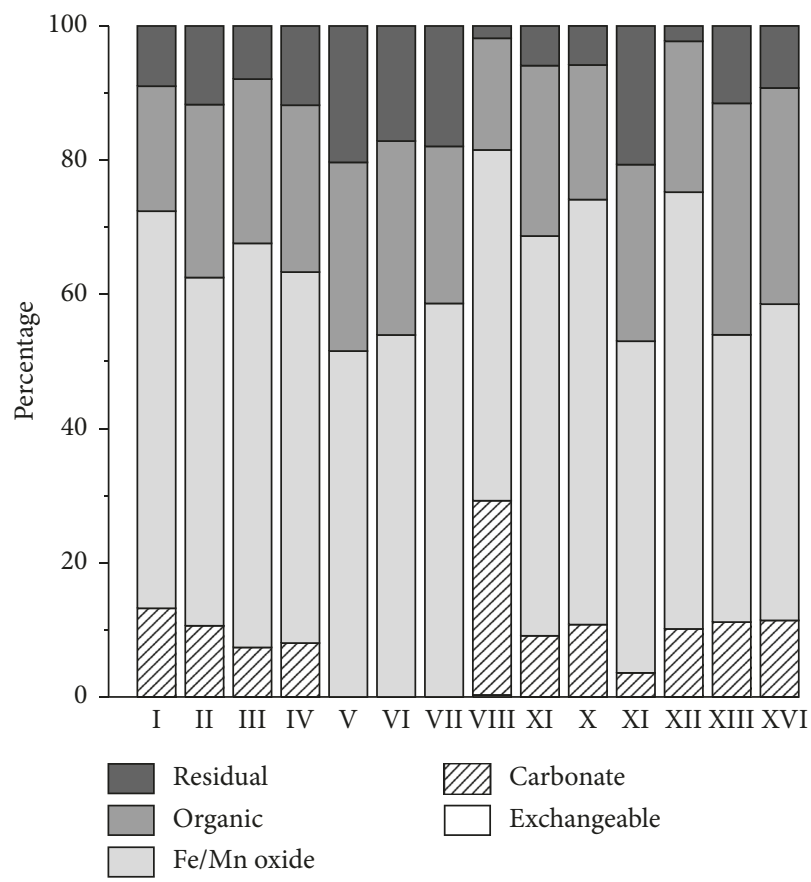

FIgURE 3: Distribution of lead in soils and sediments of the La Zacatecana Lagoon as determined by sequential extraction.

values of $\mathrm{Cr}, \mathrm{Hg}$, and $\mathrm{Ni}$ belong to class $0-1$, indicating that the La Zacatecana Lagoon soils are not contaminated by these elements (Table 5). The highest $I_{\text {geo }}$ value recorded was 7.3 for $\mathrm{Pb}$ at Site VIII, which corresponds to a highly polluted soil. $I_{\text {geo }}$ values for As indicated that La Zacatecana soils are moderately to strongly polluted by this element. By 
TABLE 5: Geoaccumulation Index $\left(I_{\text {geo }}\right)$ values of heavy metals of soils and sediments from the different sampling sites of the La Zacatecana Lagoon.

\begin{tabular}{lcccccc}
\hline \multirow{2}{*}{ Site sampling } & \multicolumn{7}{c}{$I_{\text {geo }}$} \\
& $\mathrm{Pb}$ & $\mathrm{As}$ & $\mathrm{Hg}$ & $\mathrm{Cd}$ & $\mathrm{Cr}$ & $\mathrm{Ni}$ \\
\hline I & 2.3 & 2.9 & 1.6 & 3.6 & -0.6 & 0.3 \\
II & 3.1 & 2.7 & 1.8 & $\mathrm{ND}$ & -2.5 & -1.6 \\
III & 2.6 & 2.4 & 0.3 & $\mathrm{ND}$ & -1.8 & -1.4 \\
IV & 1.9 & 2.3 & 0.6 & 3.9 & -0.8 & 0 \\
V & 1.6 & 2.1 & 0.03 & $\mathrm{ND}$ & -2.6 & -2 \\
VI & 1.3 & 2.0 & -0.6 & $\mathrm{ND}$ & -2.3 & -2.7 \\
VII & 0.6 & 1.2 & -0.7 & $\mathrm{ND}$ & -2.5 & -2.7 \\
VIII & 7.3 & 2.8 & -0.3 & $\mathrm{ND}$ & -2.7 & -3.4 \\
IX & 4.8 & 3.1 & 1.9 & $\mathrm{ND}$ & -2.7 & -2.5 \\
X & 5.3 & 4.3 & 2.0 & $\mathrm{ND}$ & -2.8 & -2.1 \\
XI & 2.2 & 2.1 & -0.4 & $\mathrm{ND}$ & -2.2 & -1.3 \\
XII & 5.3 & 4.7 & 1.0 & 2.6 & -0.7 & 0.3 \\
XIII & 2.2 & 2.1 & -0.6 & $\mathrm{ND}$ & -2.1 & -1.4 \\
XIV & 3.8 & 2.7 & -0.01 & $\mathrm{ND}$ & -1.3 & -0.5 \\
\hline
\end{tabular}

$\mathrm{ND}=$ notdetected

contrast, Cd was only detected at Sites I, IV, and XIII for which $I_{\text {geo }}$ values suggest strong pollution, although the $\mathrm{Cd}$ concentration did not exceed the maximum concentration allowed by the Mexican standard $\left(37 \mathrm{mg} \cdot \mathrm{kg}^{-1}\right)$.

Hakanson's [10] guidelines suggested that $50 \%$ of the sampling sites with an $E_{\mathrm{RI}}$ of less than 300 (Figure 4) were only at moderate environmental risk. By contrast, the other $50 \%$ of the sampling sites with $E_{\mathrm{RI}}$ values ranging from 369 to 1336 lay between considerable ecological risk to very high ecological risk-Sites II and VIII, respectively. Nevertheless, the use of international background values to estimate contamination indices can lead to an overestimation of pollution levels in soil, especially in mining areas where the parent materials contain large numbers of metals (Karbassi et al. [27]). This of course is true of the state of Zacatecas.

The results show high concentrations of $\mathrm{Pb}, \mathrm{As}$, and to a lesser extent $\mathrm{Hg}$ in the La Zacatecana Lagoon sediments. However, the metal distribution heat maps indicate that the accumulation of above metals is mainly localized in the northwest sediments of this water body. Therefore, considering that most crops grown in the bed of the lagoon in the dry season are used for local consumption, care should be exercised to avoid using this particular section for agricultural use. The latter is to avoid the possibility of introducing these contaminants into the food web trophic structure.

\section{Conclusions}

Based on Mexican and Canadian reference values for agricultural soils, our results show that soils and sediments of the La Zacatecana Lagoon are contaminated with $\mathrm{Pb}, \mathrm{As}$, and $\mathrm{Hg}$. Highest contamination levels were found in the northwest zone of the study area. The most abundant metal in the system was $\mathrm{Pb}$, but its high concentrations were probably not

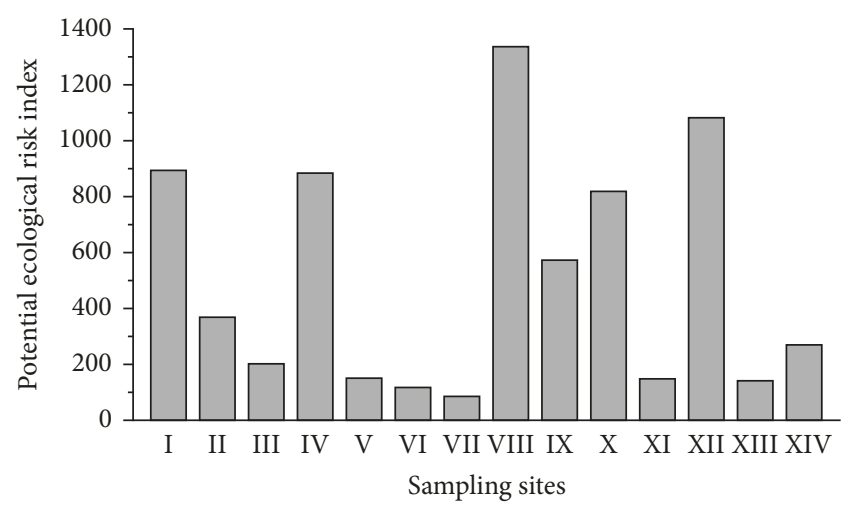

Figure 4: Potential ecological risk indices of soils and sediments from the sampling sites at the La Zacatecana Lagoon.

as harmful as seems apparent since sequential extraction tests indicated that most of the $\mathrm{Pb}(76 \%)$ were in an unavailable form bound to $\mathrm{Fe}$ and $\mathrm{Mn}$ oxides as well as organic matter. Based on $I_{\text {geo }}$ and $E_{\mathrm{RI}}$ indices, Site VIII was the most contaminated (especially with $\mathrm{Pb}$ ) of all sites in the sampling areas. High concentrations of available $\mathrm{Pb}$ at Site VIII could also be due to the high redox potential and to the low percentage of organic matter found in the soil of this site. The results obtain suggest that the population living around the La Zacatecana Lagoon should be tested for $\mathrm{Hg}$, As, and $\mathrm{Pb}$ levels in blood and urine. This is recommended as a safety measure to discard possible health complications due to heavy metal contamination, particularly in children and the elderly, which constitute the most vulnerable segment of the population.

\section{Conflicts of Interest}

The authors declare that there are no conflicts of interest regarding the publication of this research.

\section{Acknowledgments}

This research was funded by the Consejo Nacional de Ciencia y Tecnología (CONACYT, Mexico) through project FOINS-214108. The authors thank Laura Yamamoto Flores from the Universidad Autónoma de Aguascalientes and Luis E. Hernández Rodríguez and José Antonio Vera Nuñez from Cinvestav for technical assistance.

\section{References}

[1] M. S. Li, "Ecological restoration of mineland with particular reference to the metalliferous mine wasteland in China: a review of research and practice," Science of Total Environment, vol. 357, no. 1-3, pp. 38-53, 2006.

[2] A. J. M. Baker, "Accumulators and excluders strategies in the response of plants to heavy metals," Journal of Plant Nutrition, vol. 3, no. 1-4, pp. 643-654, 1981.

[3] I. Gavilán-García, E. Santos-Santos, L. R. Tovar-Gálvez, A. Gávilan-García, S. Suárez, and J. Olmos, "Mercury speciation in contaminated soils from old mining activities in Mexico using a chemical selective extraction," Journal of Mexican Chemical Society, vol. 52, no. 4, pp. 263-271, 2008. 
[4] M. A. Salas-Luevano, E. Manzanares-Acuña, C. Letechipia-de Leon, V. M. Hernandez-Davila, and H. R. Vega-Carrilllo, "Lead concentration in soil from an old mining town," Journal of Radioanalytical and Nuclear Chemistry, vol. 289, no. 1, pp. 35-39, 2001.

[5] O. G. Gonzalez-Davila, J. M. Gomez-Bernal, and E. A. RuizHuerta, "Plants and soil contamination with heavy metals in agricultural areas of Guadalupe, Zacatecas, Mexico," in Environmental Contamination, J. Srivastava, Ed., pp. 37-50, InTech, Rijeka, Croatia, 2012.

[6] F. Y. Iskander, H. R. Vega-Carrillo, and E. ManzanaresAcuña, "Determination of mercury and other elements in La Zacatecana Dam sediment in Mexico," Science of Total Environment, vol. 148, no. 1, pp. 45-48, 1994.

[7] USEPA, "Flame atomic absorption spectrophotometry (EPA method 7000B)," 2007, https://www.epa.gov/sites/ production/files/2015-12/documents/7000b.pdf.

[8] A. Walkley and I. A. Black, "An examination of the Degtjareff method for determining soil organic matter, and a proposed modification of the chromic acid titration method," Soil Science, vol. 37, no. 1, pp. 29-38, 1934.

[9] G. Müller, "Schwermetalle in den Sedimenten des Rheins Veranderungen seit 1971," Umschau, vol. 79, no. 24, pp. $778-783,1979$.

[10] L. Hakanson, "An ecological risk index for aquatic pollution control. A sedimentological approach," Water Research, vol. 14, no. 8, pp. 975-1001, 1980.

[11] A. Tessier, P. G. C. Campbell, and M. Bisson, "Sequential extraction procedure for the speciation of particulate trace metals," Analytical Chemistry, vol. 51, no. 7, pp. 844-851, 1979.

[12] DOF. Diario Oficial de la Federación, "NOM-147SEMARNAT/SSA1-2004 amprdquosemicolon.” 2005, http:// www.profepa.gob.mx/innovaportal/file/1392/1/nom-147semarnat_ssa1-2004.pdf.

[13] CCME, Canadian Environmental quality guidelines, Canadian Council of Ministers of the Environment, Winnipeg, Canada, 2017, http://ceqg-rcqe.ccme.ca/en/index.html\#void.

[14] E. Santos-Santos, M. Yarto-Ramírez, I. Gavilán-García et al., "Analysis of arsenic, lead and mercury in farming areas with mining contaminated soils at Zacatecas, Mexico," Revista de La Sociedad Química de México, vol. 50, no. 2, pp. 57-63, 2006.

[15] G. Neupane and S. J. Roberts, "Quantitative comparison of heavy metals and As accumulation in agricultural and forest soils near Bowling Green, Ohio," Water, Air, and Soil Pollution, vol. 1971, no. 1-4, pp. 289-301, 2009.

[16] F. Çevik, M. Z. L. Göksu, O. B. Derici, and Ö. Fındık, “An assessment of metal pollution in surf sediments of Seyhan dam by using enrichment factor, geoaccumulation index and statistical analyses," Environmental Monitoring Assessment, vol. 152, no. 1-4, pp. 309-317, 2009.

[17] N. A. Shafie, A. Z. Aris, M. P. Zakaria, H. Haris, W. Y. Lim, and N. M. Isa, "Application of geoaccumulation index and enrichment factors on the assessment of heavy metal pollution in the sediments," Journal of Environmental Science and Health, Part A, vol. 48, no. 2, pp. 182-190, 2013.

[18] M. C. Chuan, G. Y. Shu, and J. C. Liu, "Solubility of heavy metals in a contaminated soil: effects of redox potential and pH," Water, Air, and Soil Pollution, vol. 90, no. 3-4, pp. 543-56, 1996.

[19] R. Clemente, A. Escolar, and P. M. Bernal, "Heavy metals fractionation and organic matter mineralisation in contaminated calcareous soil amended with organic materials," Bioresource Technology, vol. 97, no. 15, pp. 1894-1901, 2006.
[20] S. R. Pezeshki, "Wetland plant responses to soil flooding," Environmental and Experimental Botany, vol. 46, no. 3, pp. 299-312, 2001.

[21] O. Husson, "Redox potential (Eh) and $\mathrm{pH}$ as drivers of soil/plant/microorganism systems: a transdisciplinary overview pointing to integrative opportunities for agronomy," Plant and Soil, vol. 362, no. 1-2, pp. 389-417, 2013.

[22] M. A. Kashem and B. R. Sing, "Metal availability in contaminated soils: I. Effects of flooding and organic matter on changes in Eh, pH and solubility of $\mathrm{Cd}, \mathrm{Ni}$ and $\mathrm{Zn}$," Nutrient Cycling in Agroecosystems, vol. 61, no. 3, pp. 247-255, 2001.

[23] A. O. Olaniran, A. Balgobind, and B. Pillay, "Bioavailability of heavy metals in soil: impact on microbial biodegradation of organic compounds and possible improvement strategies," International Journal of Molecular Sciences, vol. 14, no. 5, pp. 10197-10228, 2013.

[24] E. Steinnes, "Lead," in Heavy Metals in Soils, Trace Metals and Metalloids in Soils and their Bioavailability, B. J. Alloway, Ed., pp. 395-409, Springer, Reading, UK, 3rd edition, 2003.

[25] H. Kendorff and M. Schinitzer, "Sorption of metals on humic acid," Geochimica et Cosmochimica Acta, vol. 44, no. 11, pp. 1701-1708, 1980.

[26] M. B. McBride, Environmental Chemistry of Soils, Oxford University Press, Ney York, NY, USA, 1994.

[27] A. R. Karbassi, S. M. Monavari, Gh. R. N. Bidhendi, J. Nouri, and K. Nematpour, "Metal pollution assessment of sediment and water in the Shur River," Environmental Monitoring Assessment, vol. 147, pp. 107-116, 2008. 

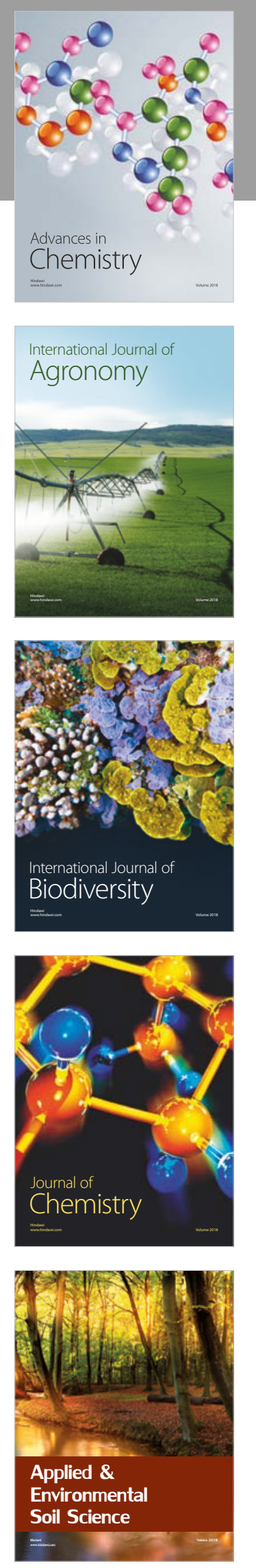

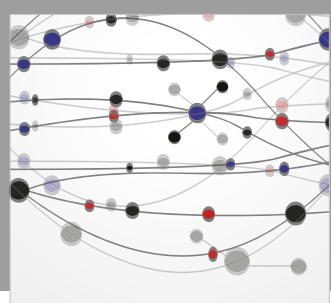

The Scientific World Journal

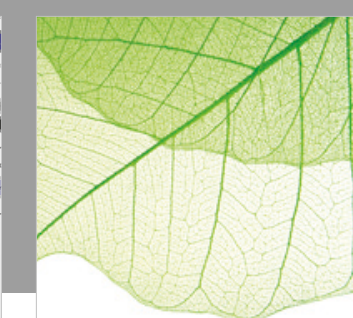

Journal of Botany

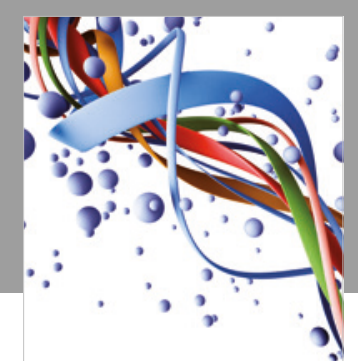

Scientifica

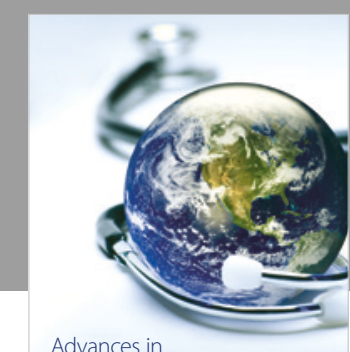

Public Health

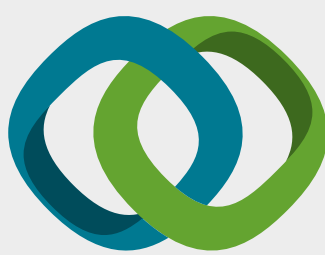

Hindawi

Submit your manuscripts at

www.hindawi.com
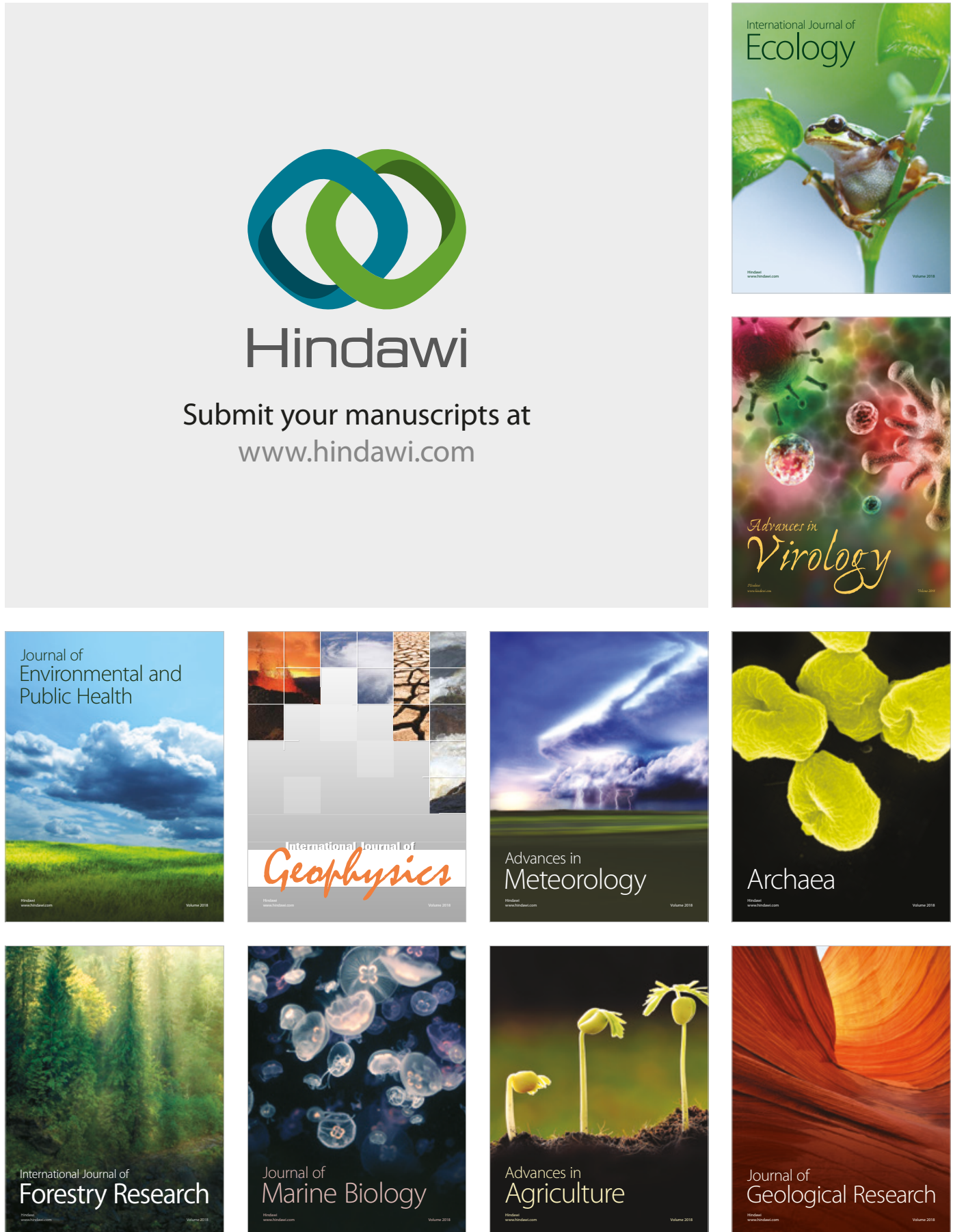

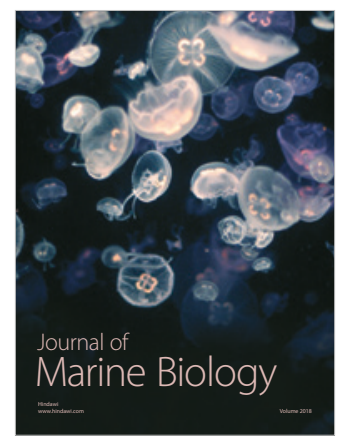

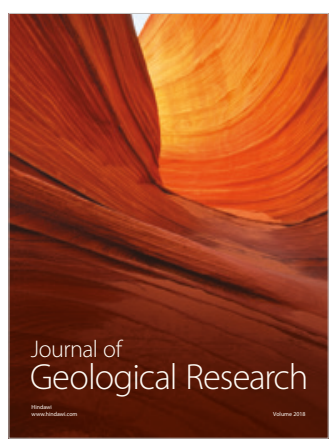

